\title{
Correction: Roles of prostaglandin F2alpha and hydrogen peroxide in the regulation of Copper/ Zinc superoxide dismutase in bovine corpus luteum and luteal endothelial cells
}

Hai V Vu, Seunghyung Lee, Tomas J Acosta*, Shin Yoshioka, Hironori Abe and Kiyoshi Okuda

\section{Correction}

After publication of this work [1], we noted that we inadvertently failed to include the complete list of all coauthors. The full list of authors has now been added and the Authors' contributions, Competing interests and Acknowledgment section have been modified accordingly.

\section{Competing interests}

The authors declare that they have no competing interests.

\section{Authors' contributions}

HW participated in the in vitro experiments, data analysis and drafted the manuscript. SL carried out the in vitro experiments, data analysis and drafted the manuscript. ShY participated in data analysis and drafted the manuscript. HA carried out the in vitro experiments. KO participated in experimental design and discussion. TJA conceived of the study, participated in its design and performed in vivo and in vitro experiments. He also helped to draft the manuscript. All authors read and approved the final manuscript.

\section{Acknowledgements}

This research has been supported by a Grant-in-Aid for Scientific Research (No.225803188) of the Japan Society for the Promotion of Science (JSPS). The authors thank Dr. DJ Skarzynski and Dr. MM Bah for the preparation of animals and for the assistance in $C L$ collection.

HW was supported by JSPS/Ronpaku dissertation program (No: VNM-11011). SHL was supported by a scholarship from the Ministry of Education, Culture, Sports, Science and Technology, Japan.
Received: 22 August 2013 Accepted: 22 August 2013

Published: 6 September 2013

\section{Reference}

1. Vu HV, Acosta TJ, Yoshioka S, Abe H, Okuda K: Roles of prostaglandin F2alpha and hydrogen peroxide in the regulation of Copper/Zinc superoxide dismutase in bovine corpus luteum and luteal endothelial cells. Reprod Biol Endocrinol 2012, 10:87.

\section{doi:10.1186/1477-7827-11-82}

Cite this article as: Vu et al:: Correction: Roles of prostaglandin F2alpha and hydrogen peroxide in the regulation of Copper/Zinc superoxide dismutase in bovine corpus luteum and luteal endothelial cells. Reproductive Biology and Endocrinology 2013 11:82.

\footnotetext{
*Correspondence: acosta@cc.okayama-u.ac.jp

Laboratory of Reproductive Physiology, Graduate School of Natural Science and Technology, Okayama University, Okayama 700-8530, Japan
}

\section{Submit your next manuscript to BioMed Central and take full advantage of: \\ - Convenient online submission \\ - Thorough peer review \\ - No space constraints or color figure charges \\ - Immediate publication on acceptance \\ - Inclusion in PubMed, CAS, Scopus and Google Scholar \\ - Research which is freely available for redistribution

